ISSN: 2162-3104 Print/ ISSN: 2166-3750 Online

Volume 8, Issue 2 (2018), pp. 597-622

(C) Journal of International Students

http://jistudents.org/

doi: $10.5281 /$ zenodo. 1249043

\title{
Influences on International Student Choice of Study Destination: Evidence from the United States
}

\author{
Sarah Nicholls \\ Michigan State University, USA
}

\begin{abstract}
Competition to attract international students continues to grow and understanding the factors that influence study destination choice is critical to the marketing efforts of nations, states, and institutions. This surveybased study of international students at Michigan State University demonstrates that they appear to choose the country in which to study, and/or the specific school, with less regard for school location. The most critical influences on their choices were expected quality of education, reputation/ranking of the university and individual departments/programs, safety/security, and cost/affordability. Differences in relative importance by nationality, gender, and level of education sought were also identified. Implications of these findings, for the marketing, promotion, and recruitment efforts of universities and national/regional economic development agencies, are discussed.
\end{abstract}

Keywords: destination choice; Michigan; study destination, international students, higher education, foreign study, affordability

The recruitment of international students to US universities is becoming an increasingly competitive export industry. US institutions vie not only against one another but also against those in other nations, especially Australia and the United Kingdom (UK), to attract the very best and brightest of this "hot global commodity" into their programs (Pandit, 2007). Yet understanding of the drivers of the choice of study location, particularly 
in a US context, is limited. As such, the focus of this paper is on identification of the factors that influence international students' decisions when choosing where to study. In the US, this choice involves three distinct spatial scales of choice: which country to study in; and, once the US has been selected, in which state and at which institution. The study therefore recognized the existence of pull factors - situational aspects of a travel destination that attract or draw visitors to it (as originally identified by, e.g., Crompton, 1979) - at all three of these levels. The research questions guiding the study were as follows: (a) what factors influence international students' choices of where to study (at the country, state and university level); (b) what is the relative importance of these three groups of factors; and (c) does their relative importance vary by sociodemographic variables such as nationality, gender or level of education sought? The study focuses on Michigan State University (MSU), a large land-grant university with a strong international presence. As is highlighted in the discussion section, the findings have important implications for university administrators, particularly with regards to the marketing of their institutions to international students.

\section{REVIEW OF LITERATURE}

Given continued growth in the number of international students, and their substantial economic impact, it is not surprising that the literature on them is also blossoming. However, very few existing studies differentiate between students by characteristics such as origin, level of education, or sociodemographic factors. The review is limited to studies of the locational choices of current or former, full time, (under) graduate international students. Shorter term programs such as Study Abroad or Erasmus were excluded since those represent fundamentally different lengths and genres of experiences. Likewise, given the focus on individual students' decisions, macro-level models of mobilities couched in the migration literature are also not reviewed in detail (see Beine, Noël \& Ragot (2014) and Perkins \& Neumayer (2014) for recent examples). Some of the studies included both domestic and international students in their samples; in those cases, only the latter findings are highlighted here. In some of the earlier studies full numeric results were not reported.

The majority of work on the topic has been empirical rather than theoretical. Much of it does reflect the overarching groups of influences 
recognized as most important in two conceptual contributions: country image, institution image, and program evaluation (Srikatanyoo \& Gnoth, 2002), to which Cubillo, Sanchez and Cervino (2006) added personal reasons and city image. The eighteen studies reviewed used a mix of survey $(61 \%)$ and qualitative (interview and focus group, 39\%) techniques. Of the eleven survey-based studies, only three appear to have employed random methods based on the entire population of international students, with the others using convenience samples of specific subsets of students. While the majority of early studies concentrated on Australia as a study destination, outbound Chinese students have emerged as a focus in the last decade. Only three of the studies reviewed were conducted in the US, compared to nine in Australia; the three US studies focused on first-year students in graduate hospitality programs, community colleges in California, and Chinese students living within a 50-mile radius of College Park, Maryland, i.e., none provide an overview of multiple types and nationalities of students.

A 1993 survey conducted by the government of Western Australia (cited in Mazzarol \& Hosie, 1996) found that the top three reasons for international students (most from Asia) to study in Australia were: proximity to home $(53 \%)$, climate/weather $(36 \%)$, and better educational opportunities (34\%). Another early study compared the experiences of 436 international and 814 domestic students at three South Australian universities (Mullins, Quintrell \& Hancock, 1995). When asked to indicate up to three main reasons for deciding to study at their current institution, the most commonly chosen responses included the university's reputation (noted by $52 \%, 20 \%$ and $18 \%$ of students across the three sites), course quality $(27 \%, 27 \%, 33 \%)$, recommendation by present/former student(s) $(25 \%, 19 \%, 23 \%)$, and cost of living considerations $(7 \%, 39 \%, 37 \%)$. Another of the earliest studies focused on 308 first-year international graduate students in 15 US hospitality programs (Huang \& Brown, 1996). When presented with a list of 14 factors related to program choice, the top four most important influences were identified as program reputation, school reputation, curriculum offered, and program faculty reputation (no statistics reported).

Unstructured interviews $(\mathrm{N}=24)$, focus groups $(\mathrm{N}=27)$ and surveys $(\mathrm{N}=803)$ of Thai students in Australia revealed that they make five basic choices before studying abroad: the decision to study abroad rather than at home, followed by choices relating to country, city, course, and university (Pimpa, 2003). Peer groups and student recruitment agencies 
were found to be important (non-familial) sources of influence. Peers tended to have the stronger impact on the decision to study abroad and the choice of country and city, whereas agents had stronger influences on the choice of course and university; peers also had a greater influence on undergraduates' decisions than graduates. A related study (Pimpa, 2005) focused on familial influence; various differences in influence based on whether or not family members had themselves studied abroad, origin (Bangkok versus other areas) and family type (nuclear, extended and alternative) were identified.

Also in Australia, Michael, Armstrong and King (2004) found that 219 international students (most from Asia) rated the quality of the education $(37 \%)$, recommendations from friends and relatives $(30 \%)$, course content $(25 \%)$ and cost $(24 \%)$ the most important reasons for their choice of Australia as a study destination (students checked all that applied from a predetermined list). When asked to list one reason why they chose to study in Perth, 297 students' responses were grouped into six categories of influence: proximity to home (24\%); cost of living (24\%); quality/variety of education (23\%); friends studying there (14\%); family recommendation (11\%); and, safety (5\%) (Shanka, Quintal \& Taylor, 2006).

Somewhat similar to the current study, Ruhanen and McLennan (2010) considered the relative importance of location (country and state), institution, and program on the choice of postgraduate studies. Their analysis focused on 101 tourism majors (domestic and international) in Queensland, Australia. The top three reasons for choosing to study in Australia (based on an open-ended question to which more than response was allowed) were: the quality of the education system (37\%); Australia's culture and lifestyle opportunities (35\%); and, affordability (19\%). International students were more likely than domestics to cite culture and lifestyle as a motivating factor, e.g., the proportion citing this factor was $48 \%$ among Chinese nationals and 64\% among SouthEast Asians. The top reasons for choosing Queensland were: climate (37\%) and its large tourism industry, presence of the School of Tourism, and the attractive landscape (all 24\%). By far the most important reason for selecting the University of Queensland was its reputation $(71 \%$ for all respondents, $83 \%$ among Chinese nationals), followed by course type (34\%) and course quality $(27 \%)$.

Also similar to the current study, Abubakar, Shanka and Muuka (2010) asked 190 international students at two institutions to identify the main reason they chose Australia, the state in, and the university at which 
they were currently studying; ten to twelve options (plus 'other') were provided for each and respondents checked one. Low cost of living was the most commonly selected reason for choosing Australia (no percentage given); choice of the east coast institution was most likely due to recommendations (14\%) and of the west, low cost of living (17\%).

Glover (2011) included questions pertaining to the choice of Australia and more specifically Brisbane/University of Queensland (UQ) as a study site. The 195 respondents were first presented with a list of 31 items related to Australia and asked to rate each one on a five-point Likert scale. The top five more highly rated items related to the desire to further career opportunities $(\mathrm{M}=3.71)$, safety $(3.70)$, providing a relaxing environment to study (3.60), weather (3.51) and difference to the home country (3.49). Among 22 items related to Brisbane/UQ, the most highly ranked items included providing a relaxing environment to study (3.44), weather (3.31) and desire to experience the lifestyle in Brisbane (3.19).

Moving to Europe and two very particular areas of study, Bourke (2000) surveyed 225 medical students (most from Malaysia and Singapore) about their choice of Ireland as a study destination. The strongest influence was the offer of a place there (noted as an influence by $76 \%$ of respondents), followed by the status of studying there (44\%). With regards the choice of institution, the most influential factors were recognition of the degree overseas (79\%), and the educational quality (71\%) and availability (69\%) of courses. With respect to 71 international students studying speech and language therapy in the UK, Goldbart, Marshall and Evans (2005) differentiated between current and past students. For the latter group, the most common reason for choosing the UK was that there was no SLT course in their home country (noted by 65\%), with the course being taught in English (35\%) and the status of UK universities (32\%) ranking second and third. For current students, the most prevalent response related to lack of a course of an equivalent level in their home country (49\%), followed by course language (41\%) and lack of any course at home (38\%) (multiple responses were allowed). Binsardi and Ekwulugo (2003) focused on the UK in general, finding that the top four, in some cases rather broad, reasons for the choice of that country as a place to study among the 62 international students surveyed were: (a) educational standards/recognition of the qualification; (b) ease of university admissions and immigration procedures; (c) ease of finding employment during and after study; and (d) cost of living and accommodations, and safety and culture. Also in the UK, but specific to 
African students, Maringe and Carter (2007) identified the international recognition of British qualifications (100\%), straightforward and easy application process $(82 \%)$, and excellent teaching and learning environment $(65 \%)$, as the three main decision factors.

The importance of three groups of factors - communication by the university before and after a student's arrival on campus, study destination attractiveness (including institutional image, program/course, language, campus environment, and cost) and social factors (influence of family and friends) - was highlighted in a Swedish context based on 16 semi-structured interviews (Phang, 2013). A similarly qualitative approach was taken to understand the increasing popularity of US community colleges among 29 international students; the study identified three major decision points: (a) the decision to study abroad (influenced by family, peers and the perceived value of an international experience); (b) the choice of a community college over a four-year institution (a second chance, a stepping stone, and an opportunity to earn legal residency); and (c) the choice of a particular community college (influenced by the presence of family/friends in the area and specific academic offerings) (Anayah \& Kuk, 2015).

Three recent studies have focused on academic mobility among Chinese university students. Based on 30 qualitative interviews, Yang (2007) identified two key motives for choosing to study in Australia: future migration opportunities, and, the offering of competitive tuition fees compared to other English-speaking countries and a high quality and worldrecognized education. Austin and Shen (2016) found that factors influencing the decision to study in the US among 20 Chinese students included: the perception of US educational institutions; the competitive advantages of a US education; university rankings; opportunities to work in the US; desire to migrate to the US; cost; and, family support. Meanwhile, an open-ended survey question indicated that the two main reasons to study in the UK were the quality of a UK university education (mentioned by $65 \%$ of the 188 respondents) and to develop English language skills (34\%) (Counsell, 2011).

\section{RESEARCH METHOD}

\section{International Students in the US, Michigan, and at MSU}

According to the Institute of International Education (IIE), there were 1,043,839 international students in the United States (US) in 2015-16, a $7.1 \%$ increase over the year prior. The four largest sources of international 
students were China (about $32 \%$ of the total), India (16\%) and Saudi Arabia and South Korea $(6 \%$ each), and the top three host states were California $(14 \%)$, New York $(11 \%)$ and Texas $(8 \%)$. The contribution of these students to the US economy was estimated at $\$ 5$ billion (IIE, 2016).

In 2014-15, Michigan hosted 32,015 international students, an 8\% increase over the year prior; in the next year international enrolment rose again, to 33,848 , a $6 \%$ increase. Michigan remains home to the ninth highest number of international students in the nation, with an economic impact approaching $\$ 1.1$ billion per annum. The top three places of study are: Michigan State University, East Lansing (8,256 international students in 2015-2016, 24\% of the Michigan total); University of Michigan, Ann Arbor (7,630, 23\%); and, Wayne State University, Detroit (3,076, 9\%). The top five sources of students were: China, 35\%; India, 17\%; Saudi Arabia, 9\%; South Korea, $6 \%$; and, Canada, $6 \%$, with the proportions of Chinese, Saudis and Canadians all several percentage points higher than the national average (IIE, 2016a, 2016b).

At MSU, home to the ninth highest number of international students in the US, students from 131 different countries represented approximately $15 \%$ of the student body in $2015-16$; over $62 \%$ of these students came from China, with another 6\% from South Korea, 5\% from India, 3\% from Saudi Arabia, and $2 \%$ from Taiwan. The number and proportion of Chinese students has seen the most rapid growth; between 2012-2013 and 20132014, the number of Chinese students at MSU rose by 19\%, representing almost one of every 11 students on campus and generating increasing news and business interest in this demographic (e.g., Miller, 2014). The annual impact of international students on the local economy has been estimated to exceed \$300 million (Office for International Students and Scholars (OISS), 2015).

\section{Sample and Survey}

In early summer 2014 a randomly selected sample of 1,100 (25\% of) MSU international students was sent a link to an electronic survey addressing the research questions listed above. The survey was offered in English and Mandarin, the latter version of which was translated and back-translated by a professional translation firm. Both versions were pretested with $50 \mathrm{MSU}$ undergraduates, approximately one half of whom were from China. A total of 378 usable responses were received, representing a $34.7 \%$ response rate after the removal of 10 undeliverable invitations (due to email inboxes being 
full). Two reminders were sent, two and four weeks after the initial participation request, and a variety of incentives was offered (one grand prize, ten runners up prizes, and a voucher for all participants).

Survey questions were derived from the existing literature with additions based on input from MSU's OISS. Six of those questions are of relevance to this paper. First, participants were asked the open-ended question "Why did you choose to study in the United States of America (USA)?" This was followed by an item that asked "How important were each of the following factors in your decision to study in the USA? Please rate the importance of each factor from not at all important to extremely important." This pairing of items was then repeated for Michigan (MI) and MSU. The number of factors presented with each closed question was as follows: USA - eight, MI - seven, MSU - eleven. Open ended responses were reviewed and categorized by theme; some students provided only one rationale, while others provided multiple. Closed ended responses were tallied and subjected to difference of means testing using SPSS.

\section{FINDINGS}

First, an overview of the characteristics of the sample is provided. Then, the open and closed ended responses regarding reasons for studying in the USA and MI, and at MSU, are summarized. Finally, results of differences of means tests are presented.

\section{Characteristics of the Sample}

Respondents were $44 \%$ male and $56 \%$ female; $41 \%$ were aged 18 22 years old and $59 \%$ aged 23 years or older (with a range from 18 to 52 and an average of 26.15 years). Over one half (53\%) of respondents were from China, with $7 \%$ from India, $4 \%$ from Canada, $4 \%$ from Korea, and the remaining $32 \%$ from 40 other countries. Most (51\%) were enrolled in a fulltime graduate program (of which $21 \%$ were in a master's program and $79 \%$ doctoral), with $45 \%$ enrolled in a full-time undergraduate program and $4 \%$ in another type of shorter-term program. The respondents were studying a total of 92 different degree subjects, with the most commonly represented majors including accounting (6\%), advertising (5\%), elementary education $(5 \%)$, finance $(5 \%)$ and music education $(5 \%)$. 


\section{Reasons for choosing to study in the US}

By far the most prevalent response to the open-ended version of this question related to the expected quality of a US education; about $35 \%$ of the students identified the quality of the US education system as a reason for their choice. The next most common response related to the research opportunities available in the US (mentioned by about $10 \%$ of respondents), followed by the quality of the MSU department or program in which the student is enrolled (7\%). Other items mentioned by more than $5 \%$ of respondents related to the availability of financial assistance or a scholarship, the opportunity to experience the American lifestyle and culture, and the job opportunities afforded by an education in the US.

Table 1. Factors Influencing Decision to Study in the USA (ranked by M)

\begin{tabular}{|c|c|c|c|c|c|c|}
\hline & 1 & 2 & 3 & 4 & 5 & $\begin{array}{l}\text { Mean } \\
(\mathrm{SD})\end{array}$ \\
\hline $\begin{array}{l}\text { Expected quality } \\
\text { of education in } \\
\text { USA }\end{array}$ & $\begin{array}{c}3 \\
(0.8 \%)\end{array}$ & $\begin{array}{c}2 \\
(0.5 \%)\end{array}$ & $\begin{array}{c}20 \\
(5.4 \%)\end{array}$ & $\begin{array}{c}130 \\
(34.3 \%)\end{array}$ & $\begin{array}{c}223 \\
(59.0 \%)\end{array}$ & $\begin{array}{c}4.50 \\
(0.70)\end{array}$ \\
\hline $\begin{array}{l}\text { Affordability of } \\
\text { studying in USA }\end{array}$ & $\begin{array}{c}22 \\
(5.8 \%)\end{array}$ & $\begin{array}{c}17 \\
(4.5 \%)\end{array}$ & $\begin{array}{c}69 \\
(18.2 \%)\end{array}$ & $\begin{array}{c}149 \\
(39.4 \%)\end{array}$ & $\begin{array}{c}121 \\
(32.1 \%)\end{array}$ & $\begin{array}{c}3.88 \\
(1.04)\end{array}$ \\
\hline $\begin{array}{l}\text { Level of safety } \\
\text { and security in } \\
\text { USA }\end{array}$ & $\begin{array}{c}20 \\
(5.3 \%)\end{array}$ & $\begin{array}{c}36 \\
(9.5 \%)\end{array}$ & $\begin{array}{c}81 \\
(21.4 \%)\end{array}$ & $\begin{array}{c}156 \\
(41.3 \%)\end{array}$ & $\begin{array}{c}84 \\
(22.3 \%)\end{array}$ & $\begin{array}{c}3.66 \\
(1.05)\end{array}$ \\
\hline $\begin{array}{l}\text { Language(s) } \\
\text { spoken in USA }\end{array}$ & $\begin{array}{c}39 \\
(10.3 \%)\end{array}$ & $\begin{array}{c}34 \\
(9.0 \%)\end{array}$ & $\begin{array}{c}81 \\
(21.4 \%)\end{array}$ & $\begin{array}{c}131 \\
(34.7 \%)\end{array}$ & $\begin{array}{c}92 \\
(24.3 \%)\end{array}$ & $\begin{array}{c}3.54 \\
(1.13)\end{array}$ \\
\hline $\begin{array}{l}\text { Opportunities to } \\
\text { travel while in } \\
\text { USA }\end{array}$ & $\begin{array}{c}47 \\
(12.4 \%)\end{array}$ & $\begin{array}{c}67 \\
(17.8 \%)\end{array}$ & $\begin{array}{c}106 \\
(28.1 \%)\end{array}$ & $\begin{array}{c}100 \\
(26.4 \%)\end{array}$ & $\begin{array}{c}58 \\
(15.3 \%)\end{array}$ & $\begin{array}{l}3.14 \\
(1.14)\end{array}$ \\
\hline $\begin{array}{l}\text { Recommendation } \\
\text { of educational } \\
\text { agent }\end{array}$ & $\begin{array}{c}170 \\
(45.0 \%)\end{array}$ & $\begin{array}{c}55 \\
(14.6 \%)\end{array}$ & $\begin{array}{c}55 \\
(14.6 \%)\end{array}$ & $\begin{array}{c}67 \\
(17.7 \%)\end{array}$ & $\begin{array}{c}31 \\
(8.2 \%)\end{array}$ & $\begin{array}{l}2.30 \\
(1.28)\end{array}$ \\
\hline $\begin{array}{l}\text { Friends/relatives } \\
\text { already living in } \\
\text { USA }\end{array}$ & $\begin{array}{c}174 \\
(46.0 \%)\end{array}$ & $\begin{array}{c}81 \\
(21.5 \%)\end{array}$ & $\begin{array}{c}69 \\
(18.2 \%)\end{array}$ & $\begin{array}{c}37 \\
(9.8 \%)\end{array}$ & $\begin{array}{c}17 \\
(4.5 \%)\end{array}$ & $\begin{array}{l}2.06 \\
(1.12)\end{array}$ \\
\hline $\begin{array}{l}\text { Proximity of } \\
\text { USA to home } \\
\text { country }\end{array}$ & $\begin{array}{c}174 \\
(46.0 \%)\end{array}$ & $\begin{array}{c}86 \\
(22.7 \%)\end{array}$ & $\begin{array}{c}62 \\
(16.5 \%)\end{array}$ & $\begin{array}{c}40 \\
(10.7 \%)\end{array}$ & $\begin{array}{c}16 \\
(4.1 \%)\end{array}$ & $\begin{array}{c}2.05 \\
(1.15)\end{array}$ \\
\hline
\end{tabular}


When presented with the list of eight factors to rate, the most important item in the decision-making process matched the open-ended responses; $59.0 \%$ of respondents rated the expected quality of education in the USA as extremely important, and another $34.3 \%$ very important $(\mathrm{M}=$ 4.50). Affordability of studying in the USA (3.88), level of safety/security (3.66) and language(s) spoken were the next most highly rated items. The full set of responses to each item is presented in Table 1 .

\section{Reasons for Choosing to Study in MI}

The most common response to the open-ended version of this question related to the expected quality of the MSU program in which the student was enrolled; about $18 \%$ of respondents mentioned this item. The next most common response related to MSU's rank or reputation (8\%), followed by the availability of financial assistance or a scholarship (5\%). The next most commonly mentioned item, and the highest-ranking item that relates to Michigan as a state rather than a factor specific to MSU, was Michigan's natural scenery and environment (5\%).

Table 2. Factors Influencing Decision to Study in Michigan (MI) (ranked by M)

\begin{tabular}{|c|c|c|c|c|c|c|}
\hline & 1 & 2 & 3 & 4 & 5 & $\begin{array}{l}\text { Mean } \\
(\mathrm{SD})\end{array}$ \\
\hline $\begin{array}{l}\text { Level of safety and } \\
\text { security in MI }\end{array}$ & $\begin{array}{c}67 \\
(17.7 \%)\end{array}$ & $\begin{array}{c}53 \\
(14.0)\end{array}$ & $\begin{array}{c}102 \\
(27.0 \%)\end{array}$ & $\begin{array}{c}99 \\
(26.2 \%)\end{array}$ & $\begin{array}{c}57 \\
(15.1 \%)\end{array}$ & $\begin{array}{c}3.07 \\
(1.30)\end{array}$ \\
\hline $\begin{array}{l}\text { Beauty of MI's } \\
\text { natural scenery }\end{array}$ & $\begin{array}{c}97 \\
(25.7 \%)\end{array}$ & $\begin{array}{c}104 \\
(27.5 \%)\end{array}$ & $\begin{array}{c}98 \\
(25.9 \%)\end{array}$ & $\begin{array}{c}61 \\
(16.1 \%)\end{array}$ & $\begin{array}{c}18 \\
(4.8 \%)\end{array}$ & $\begin{array}{c}2.47 \\
(1.15)\end{array}$ \\
\hline $\begin{array}{l}\text { Location of MI on } \\
\text { the Great Lakes }\end{array}$ & $\begin{array}{c}131 \\
(34.7 \%)\end{array}$ & $\begin{array}{c}98 \\
(25.9 \%)\end{array}$ & $\begin{array}{c}81 \\
(21.4 \%)\end{array}$ & $\begin{array}{c}48 \\
(12.7 \%)\end{array}$ & $\begin{array}{c}20 \\
(5.3 \%)\end{array}$ & $\begin{array}{c}2.28 \\
(1.21)\end{array}$ \\
\hline $\begin{array}{l}\text { Weather/climate in } \\
\text { MI }\end{array}$ & $\begin{array}{c}139 \\
(36.8 \%)\end{array}$ & $\begin{array}{c}90 \\
(23.8 \%)\end{array}$ & $\begin{array}{c}79 \\
(20.9 \%)\end{array}$ & $\begin{array}{c}47 \\
(12.4 \%)\end{array}$ & $\begin{array}{c}23 \\
(6.1 \%)\end{array}$ & $\begin{array}{c}2.27 \\
(1.23)\end{array}$ \\
\hline $\begin{array}{l}\text { Recommendation } \\
\text { of educational } \\
\text { agent }\end{array}$ & $\begin{array}{c}162 \\
(42.9 \%)\end{array}$ & $\begin{array}{c}71 \\
(18.8 \%)\end{array}$ & $\begin{array}{c}69 \\
(18.3 \%)\end{array}$ & $\begin{array}{c}63 \\
(14.0 \%)\end{array}$ & $\begin{array}{c}23 \\
(6.1 \%)\end{array}$ & $\begin{array}{c}2.22 \\
(1.29)\end{array}$ \\
\hline $\begin{array}{l}\text { Central location of } \\
\text { MI within the US }\end{array}$ & $\begin{array}{c}130 \\
(34.4 \%)\end{array}$ & $\begin{array}{c}114 \\
(30.2 \%)\end{array}$ & $\begin{array}{c}84 \\
(22.2 \%)\end{array}$ & $\begin{array}{c}39 \\
(10.3 \%)\end{array}$ & $\begin{array}{c}11 \\
(2.9 \%)\end{array}$ & $\begin{array}{c}2.17 \\
(1.10)\end{array}$ \\
\hline $\begin{array}{l}\text { Friends/relatives } \\
\text { already in MI }\end{array}$ & $\begin{array}{c}236 \\
(62.4 \%)\end{array}$ & $\begin{array}{c}63 \\
(16.7 \%)\end{array}$ & $\begin{array}{c}39 \\
(10.3 \%)\end{array}$ & $\begin{array}{c}21 \\
(5.6 \%)\end{array}$ & $\begin{array}{c}19 \\
(5.0 \%)\end{array}$ & $\begin{array}{c}1.74 \\
(1.16)\end{array}$ \\
\hline
\end{tabular}

Note. $1=$ not at all important; $2=$ a little important; $3=$ somewhat important; $4=$ very important; $5=$ extremely important; $\mathrm{SD}=$ standard deviation 
Table 3. Importance of Factors Influencing Decision to Study at MSU (ranked by M)

\begin{tabular}{|c|c|c|c|c|c|c|}
\hline & 1 & 2 & 3 & 4 & 5 & $\begin{array}{l}\text { Mean } \\
(\mathrm{SD})\end{array}$ \\
\hline $\begin{array}{l}\text { Reputation of } \\
\text { degree program }\end{array}$ & $\begin{array}{c}10 \\
(2.6 \%)\end{array}$ & $\begin{array}{c}11 \\
(2.9 \%)\end{array}$ & $\begin{array}{c}50 \\
(13.2 \%)\end{array}$ & $\begin{array}{c}120 \\
(31.7 \%)\end{array}$ & $\begin{array}{c}187 \\
(49.5 \%)\end{array}$ & $\begin{array}{c}4.22 \\
(0.97)\end{array}$ \\
\hline $\begin{array}{l}\text { General reputation } \\
\text { of } \mathrm{MSU}\end{array}$ & $\begin{array}{c}12 \\
(3.2 \%)\end{array}$ & $\begin{array}{c}21 \\
(5.6 \%)\end{array}$ & $\begin{array}{c}74 \\
(19.6 \%)\end{array}$ & $\begin{array}{c}156 \\
(41.3 \%)\end{array}$ & $\begin{array}{c}115 \\
(30.4 \%)\end{array}$ & $\begin{array}{c}3.90 \\
(1.00)\end{array}$ \\
\hline $\begin{array}{l}\text { Content of courses } \\
\text { offered at MSU }\end{array}$ & $\begin{array}{c}16 \\
(4.2 \%)\end{array}$ & $\begin{array}{c}21 \\
(5.6 \%)\end{array}$ & $\begin{array}{c}77 \\
(20.4 \%)\end{array}$ & $\begin{array}{c}152 \\
(40.2 \%)\end{array}$ & $\begin{array}{c}112 \\
(29.6 \%)\end{array}$ & $\begin{array}{c}3.85 \\
(1.02)\end{array}$ \\
\hline $\begin{array}{l}\text { Affordability of } \\
\text { studying at MSU }\end{array}$ & $\begin{array}{c}25 \\
(6.6 \%)\end{array}$ & $\begin{array}{c}40 \\
(10.6 \%)\end{array}$ & $\begin{array}{c}77 \\
(20.4 \%)\end{array}$ & $\begin{array}{c}132 \\
(34.9 \%)\end{array}$ & $\begin{array}{c}104 \\
(27.5 \%)\end{array}$ & $\begin{array}{c}3.66 \\
(1.17)\end{array}$ \\
\hline $\begin{array}{l}\text { Availability of } \\
\text { student housing at } \\
\text { MSU }\end{array}$ & $\begin{array}{c}65 \\
(17.2 \%)\end{array}$ & $\begin{array}{c}80 \\
(21.2 \%)\end{array}$ & $\begin{array}{c}114 \\
(30.2 \%)\end{array}$ & $\begin{array}{c}85 \\
(22.5 \%)\end{array}$ & $\begin{array}{c}34 \\
(9.0 \%)\end{array}$ & $\begin{array}{l}2.85 \\
(1.20)\end{array}$ \\
\hline Beauty of the & 72 & 77 & 123 & 82 & 24 & 2.76 \\
\hline MSU campus & $(19.0 \%)$ & $(20.4 \%)$ & $(32.5 \%)$ & $(21.7 \%)$ & $(6.3 \%)$ & $(1.16)$ \\
\hline $\begin{array}{l}\text { Number of other } \\
\text { international } \\
\text { students }\end{array}$ & $\begin{array}{c}110 \\
(29.1 \%)\end{array}$ & $\begin{array}{c}83 \\
(22.0 \%)\end{array}$ & $\begin{array}{c}97 \\
(25.7 \%)\end{array}$ & $\begin{array}{c}61 \\
(16.1 \%)\end{array}$ & $\begin{array}{c}24 \\
(6.3 \%)\end{array}$ & $\begin{array}{l}2.50 \\
(1.25)\end{array}$ \\
\hline Reputation of East & 104 & 94 & 95 & 63 & 22 & 2.48 \\
\hline $\begin{array}{l}\text { Lansing as a city } \\
\text { to live }\end{array}$ & $(27.5 \%)$ & $(24.9 \%)$ & $(25.1)$ & $(16.7 \%)$ & $(5.8 \%)$ & $(1.21)$ \\
\hline Reputation of & 154 & 78 & 66 & 44 & 36 & 2.29 \\
\hline $\begin{array}{l}\text { MSU's sports } \\
\text { teams }\end{array}$ & $(40.7 \%)$ & $(20.6 \%)$ & $(17.5 \%)$ & $(11.6 \%)$ & $(9.5 \%)$ & $(1.35)$ \\
\hline $\begin{array}{l}\text { Recommendation } \\
\text { of educational } \\
\text { agent }\end{array}$ & $\begin{array}{c}160 \\
(42.3 \%)\end{array}$ & $\begin{array}{c}69 \\
(18.3 \%)\end{array}$ & $\begin{array}{c}64 \\
(16.9 \%)\end{array}$ & $\begin{array}{c}61 \\
(16.1 \%)\end{array}$ & $\begin{array}{c}24 \\
(6.3 \%)\end{array}$ & $\begin{array}{c}2.26 \\
(1.31)\end{array}$ \\
\hline $\begin{array}{l}\text { Friends/relatives } \\
\text { who have studied } \\
\text { at MSU }\end{array}$ & $\begin{array}{c}194 \\
(51.3 \%)\end{array}$ & $\begin{array}{c}83 \\
(22.0 \%)\end{array}$ & $\begin{array}{c}51 \\
(13.5 \%)\end{array}$ & $\begin{array}{c}33 \\
(8.7 \%)\end{array}$ & $\begin{array}{c}17 \\
(4.5 \%)\end{array}$ & $\begin{array}{c}1.93 \\
(1.18)\end{array}$ \\
\hline
\end{tabular}

Note. $1=$ not at all important; $2=$ a little important; $3=$ somewhat important; $4=$ very important; $5=$ extremely important; $\mathrm{SD}=$ standard deviation

In the closed version of this question, the highest rated factor related to safety and security. However, the mean score on the item was only 3.07, with the most common response indicating that safety/security is somewhat important. The beauty of MI's natural scenery, the most commonly 
mentioned state-specific item in the open-ended question, was the second most highly rated factor, with the same proportion of respondents identifying that as an extremely important factor in their decision as independently identified that factor in their open-ended response. However, this and all other items received mean scores below 3.0 on the five-point importance scale. The full set of responses is presented in Table 2.

Table 4. Importance of Factors Influencing Decision to Study in the USA by Nationality, Gender and Education Level

\begin{tabular}{|c|c|c|c|c|c|c|}
\hline & \multicolumn{2}{|c|}{ Nationality } & \multicolumn{2}{|c|}{ Gender } & \multicolumn{2}{|c|}{ Level } \\
\hline & Chinese & Other & Male & Female & Under. & Grad. \\
\hline $\begin{array}{l}\text { Expected quality } \\
\text { of education in } \\
\text { USA }\end{array}$ & 4.37 & 4.50 & 4.39 & 4.46 & $4.33 * * *$ & $4.58 * * *$ \\
\hline $\begin{array}{l}\text { Affordability of } \\
\text { studying in USA }\end{array}$ & $3.65 * *$ & $3.90 * *$ & 3.72 & 3.83 & $3.57 * * *$ & $3.94 * * *$ \\
\hline $\begin{array}{l}\text { Level of safety } \\
\text { and security in } \\
\text { USA }\end{array}$ & $3.78 * *$ & $3.56^{* *}$ & $3.53 * *$ & $3.79 * *$ & 3.73 & 3.61 \\
\hline $\begin{array}{l}\text { Language(s) } \\
\text { spoken in USA }\end{array}$ & 3.45 & 3.57 & 3.39 & 3.57 & 3.48 & 3.54 \\
\hline $\begin{array}{l}\text { Opportunities to } \\
\text { travel in USA }\end{array}$ & 3.12 & 3.12 & $2.92 * * *$ & $3.29 * * *$ & 3.25 & 3.02 \\
\hline $\begin{array}{l}\text { Recommendation } \\
\text { of educational } \\
\text { agent }\end{array}$ & 2.45 & 2.34 & 2.36 & 2.40 & $2.79 * * *$ & $2.03 * * *$ \\
\hline $\begin{array}{l}\text { Friends/relatives } \\
\text { already in USA }\end{array}$ & 2.23 & 2.02 & 2.15 & 2.08 & 2.19 & 2.03 \\
\hline $\begin{array}{l}\text { Proximity of } \\
\text { USA to home } \\
\text { country }\end{array}$ & $2.40 * * *$ & $1.98 * * *$ & 2.19 & 2.15 & $2.43 * * *$ & $1.97 * * *$ \\
\hline
\end{tabular}

\section{Reasons for Choosing to Study at MSU}

When asked about their choice of MSU in an open-ended manner, by far the most prevalent response related to the quality of the particular program or department in which the student was enrolled; about $31 \%$ of the students provided a response pertaining to program or departmental excellence. The next most common response related to MSU's general rank or reputation (18\%), followed by the research opportunities available at the 
university $(8 \%)$. No other item was mentioned by more than $5 \%$ of respondents.

Table 5. Importance of Factors Influencing Decision to Study in Michigan (MI)

\begin{tabular}{lcccccc}
\hline & \multicolumn{2}{c}{ Nationality } & \multicolumn{2}{c}{ Gender } & \multicolumn{2}{c}{ Level } \\
\cline { 2 - 7 } & Chinese & Other & Male & Female & Under. & Grad. \\
\hline $\begin{array}{l}\text { Level of safety and } \\
\text { security in MI }\end{array}$ & 3.19 & 2.93 & $2.92^{* *}$ & $3.19^{* *}$ & $3.22^{* *}$ & $2.91^{* *}$ \\
$\begin{array}{l}\text { Beauty of MI's } \\
\text { natural scenery }\end{array}$ & 2.50 & 2.41 & 2.43 & 2.50 & $2.59^{* *}$ & $2.31^{* *}$ \\
$\begin{array}{l}\text { Location of MI on } \\
\text { the Great Lakes }\end{array}$ & $2.42^{* *}$ & $2.12^{* *}$ & 2.31 & 2.26 & $2.44^{* * *}$ & $2.09^{* * *}$ \\
$\begin{array}{l}\text { Weather/climate in } \\
\text { MI }\end{array}$ & $2.42^{* *}$ & $2.09^{* *}$ & 2.23 & 2.31 & $2.52^{* * *}$ & $2.01^{* * *}$ \\
$\begin{array}{l}\text { Recommendation } \\
\text { of educational }\end{array}$ & 2.08 & 2.34 & 2.22 & 2.19 & $2.52^{* * *}$ & $1.92^{* * *}$ \\
$\begin{array}{l}\text { agent } \\
\text { Central location of }\end{array}$ & 2.16 & 2.16 & 2.18 & 2.16 & 2.26 & 2.05 \\
$\begin{array}{l}\text { MI within the US } \\
\text { Friends/relatives } \\
\text { already living in }\end{array}$ & 1.63 & 1.86 & 1.80 & 1.71 & 1.70 & 1.77 \\
MI & & & & & & \\
\hline Note. $* * * \mathrm{p}<.01, * * \mathrm{p}<.05$ & & & & & \\
\end{tabular}

According to the closed responses, the four most important factors in the choice of MSU were as follows: reputation of the degree program in which the student is enrolled (49.5\% extremely important, $31.7 \%$ very important, $\mathrm{M}=4.22)$; general reputation of MSU (30.4\%, 41.3\%, 3.90); content of courses offered $(29.6 \%, 40.2 \%, 3.85)$; and, affordability $(27.5 \%, 34.9 \%$, 3.66). The least important factors included the reputation of MSU's sports teams $(\mathrm{M}=2.29)$, the recommendation of an educational agent (2.26) and friends/relatives who have studied at MSU (1.93). The full set of responses to each item is presented in Table 3 .

\section{Difference of Means Testing}

Mean scores for each of the three sets of items (USA, MI, MSU) were subjected to difference of means tests to identify any significant variation in responses between three sets of groups: students of Chinese 
Table 6. Importance of Factors Influencing Decision to Study at MSU

\begin{tabular}{|c|c|c|c|c|c|c|}
\hline & \multicolumn{2}{|c|}{ Nationality } & \multicolumn{2}{|c|}{ Gender } & \multicolumn{2}{|c|}{ Level } \\
\hline & Chinese & Other & Male & Female & Under. & Grad. \\
\hline $\begin{array}{l}\text { Reputation of } \\
\text { degree program }\end{array}$ & $4.07 * * *$ & $4.40 * * *$ & 4.19 & 4.28 & $3.99 * * *$ & $4.44 * * *$ \\
\hline $\begin{array}{l}\text { General } \\
\text { reputation of } \\
\text { MSU }\end{array}$ & $3.75 * * *$ & $4.04 * * *$ & 3.89 & 3.91 & 3.82 & 3.98 \\
\hline $\begin{array}{l}\text { Content of } \\
\text { courses offered } \\
\text { at MSU }\end{array}$ & $3.73 * *$ & $4.00 * *$ & 3.80 & 3.92 & 3.86 & 3.83 \\
\hline $\begin{array}{l}\text { Affordability of } \\
\text { studying at } \\
\text { MSU }\end{array}$ & $3.52 * *$ & $3.82 * *$ & 3.64 & 3.74 & $3.41 * * *$ & $3.89 * * *$ \\
\hline $\begin{array}{l}\text { Availability of } \\
\text { student housing } \\
\text { at MSU }\end{array}$ & 2.74 & 2.96 & 2.73 & 2.96 & 2.94 & 2.75 \\
\hline $\begin{array}{l}\text { Beauty of the } \\
\text { MSU campus }\end{array}$ & 2.83 & 2.65 & 2.75 & 2.75 & $3.04 * * *$ & $2.49 * * *$ \\
\hline $\begin{array}{l}\text { Number of other } \\
\text { international } \\
\text { students at MSU }\end{array}$ & 2.56 & 2.41 & 2.61 & 2.42 & $2.75^{* * *}$ & $2.24 * * *$ \\
\hline $\begin{array}{l}\text { Reputation of } \\
\text { East Lansing as } \\
\text { a city in which } \\
\text { to live }\end{array}$ & 2.46 & 2.49 & 2.53 & 2.47 & $2.61 * *$ & $2.33 * *$ \\
\hline $\begin{array}{l}\text { Reputation of } \\
\text { MSU's sports } \\
\text { teams }\end{array}$ & 2.30 & 2.28 & $2.47 * *$ & $2.19 * *$ & $2.60 * * *$ & $1.96 * * *$ \\
\hline $\begin{array}{l}\text { Recommenda- } \\
\text { tion of } \\
\text { educational } \\
\text { agent }\end{array}$ & $2.08 * *$ & $2.43 * *$ & 2.27 & 2.24 & $2.58 * * *$ & $1.94 * * *$ \\
\hline $\begin{array}{l}\text { Friends/relatives } \\
\text { who have } \\
\text { studied at MSU }\end{array}$ & 1.82 & 2.06 & $2.08 * *$ & $1.83 * *$ & 1.92 & 1.93 \\
\hline
\end{tabular}

versus any other national origin; male versus female; and, those enrolled in graduate versus undergraduate study. The $4 \%$ of students enrolled in a shortterm program were excluded from the latter test, thus, the proportions of 
respondents in each group were as follows: Chinese, 53\%, other national origin, $47 \%$; male, $44 \%$, female, $56 \%$; and, graduate students, $53 \%$, undergraduate students, $47 \%$.

Reasons for choosing to study in the USA. As shown in Table 4, Chinese students were significantly more concerned about level of safety/security, and about proximity to home, than students from other nations, though less concerned about affordability. Females were more influenced by level of safety/security and opportunities to travel than males. Undergraduates were more influenced by the recommendation of an educational agent and by proximity to home than graduate students, though less influenced by educational quality and affordability.

\section{Reasons for choosing to study in MI.}

As indicated in Table 5, Chinese students considered Michigan's location on the Great Lakes and its weather/climate significantly more important in their study location decision than other nationalities. Females were influenced more than males by safety/security, and undergraduates more influenced than graduate students by safety/security; Michigan's natural scenery, location on the Great Lakes, and weather/climate; and, an education agent.

\section{Reasons for choosing to study at MSU.}

Chinese students were significantly less influenced by university or degree reputation, course content, affordability, or an educational agent, than other nationalities (Table 6). Males were more influenced by the reputation of MSU's sports teams, and by friends/relatives who have studied at MSU, than females. Undergraduate students placed more emphasis on the beauty of campus, the number of other international students, an agent's recommendation, and the reputations of East Lansing and of MSU's sports teams, than graduate students, though were less influenced by degree reputation and affordability.

\section{DISCUSSION AND IMPLICATIONS}

This study represents the first known large-scale analysis of international students' decision-making process with respect to studying in the US, revealing several noteworthy aspects with respect to factors influencing where they study. As a whole, it appears that international students appear to 
choose a country in which to study, and/or a specific school, with less regard for the school's location. If the eight USA-specific, seven MI and eleven MSU factors were combined, factors relating to Michigan would occupy six of the twelve lowest rankings; mean scores fell below 3.0 (less than somewhat important) for six of the seven MI factors.

In the case of both cost/affordability and safety/security, there was an interesting disconnect between the lack of identification of these factors as important to the decision-making process in the open-ended questions, and their consistently higher rating and ranking in the closed items. While the availability of financial assistance or a scholarship was mentioned as a reason to choose the USA or Michigan by only about $5 \%$ of respondents in both cases in the open-ended questions, affordability was the second (of eight) most highly rated factor when choosing the USA $(39.4 \%$ very important, $32.1 \%$ extremely important, $\mathrm{M}=3.88$ ) and fourth of eleven when choosing MSU $(34.9 \%, 27.5 \%, 3.66)$. In the open-ended questions, safety/security was mentioned by two respondents $(0.5 \%)$ with respect to their choice of both MI and MSU and was never mentioned with respect to the USA. Yet safety/security ranked third of eight factors with respect to choice of the USA $(41.3 \%$ very important, $22.3 \%$, extremely important, $\mathrm{M}=$ $3.66)$ and first for MI $(26.2 \%, 15.1 \%, 3.07)$ in the closed questions. Though perhaps not top-of-mind once at an institution, when prompted respondents were clearly reminded of the extent to which these factors influenced their decisions prior to their arrival.

Significant differences were recorded regarding the influence of affordability (of the USA and of MSU) between Chinese students and those of other nationalities, and undergraduates and graduate students. In both cases (USA and MSU), affordability was rated more important by the nonChinese and the graduate students. Though data on family or individual income for any student groups are not available, anecdotal observation and local media coverage of the ownership of luxury branded products such as clothes, accessories and cars (e.g., Anders, 2014), would suggest that many of the Chinese students on MSU's campus come from relatively affluent backgrounds; their lower concern with price is therefore not surprising.

Safety has ranked similarly high in other recent contexts, e.g., second of 31 items $(M=3.7 / 5.0)$ for Australia (Glover, 2011). However, in Mazzarol and Soutar's (2001) summary of three prior studies of prospective students from China, India, Indonesia and Taiwan, the percentages of students indicating that safety was an important influence on destination 
selection were relatively low compared to other factors such as course quality, especially among Indian and Chinese students. However, the safety factor in that study referred specifically to crime, whereas it seems plausible that safety/security in a more general sense has become a more important consideration post $9 / 11$, though no study appears to have tested this supposition. The importance of perceived levels of safety and security is well-established in the broader travel literature (e.g., Tourism Australia, 2016; Zhang, Qu \& Tang, 2004). Female students in this study expressed significantly greater levels of concern regarding safety/security than males. Though no studies appear to have addressed this gender differential in the context of international students, both the academic literature and the media have explored the tendency for women to experience higher levels of apprehension regarding their personal safety than men (e.g., Crabtree \& Nsubuga, 2012; Ratti, 2010; Smith \& Torstensson, 1997).

The influence of friends and relatives was low among the entire sample. The presence of friends/relatives ranked seven of eight among the factors relating to choice of the USA (45.9\% not at all important, $21.5 \%$ a little important, $M=2.06)$ and seventh (last) for Michigan $(62.4 \%, 16.7 \%$, 1.74). Likewise, the influence of friends/relatives who have studied at MSU ranked eleventh (last) $(51.3 \%, 22.0 \%, 1.93)$. These findings contrast with Anayah and Kuk's (2015) observation that the presence of family/friends was often the most decisive factor in the choice of a particular community college. However, the current findings complement other studies that have also found lower support for the importance of friends/relatives in the study location, e.g., the item 'I have family/friends who are studying/have studied in Australia' ranked 23 of 31 items $(\mathrm{M}=2.59 / 5.0)$ and 'somebody from my family lives in Australia' ranked 30 of 31 items (1.94) according to Glover (2011). Mazzarol and Soutar (2001) considered both recommendations from, and the presence of, friends and/or relatives. A parent's/relative's recommendation of a nation was an important influence for $52 \%$ of Chinese, $60 \%$ of Indian, $80 \%$ of Indonesian, and $67 \%$ of Taiwanese students; proportions relating to having a friend/relative studying there were $47 \%$, $75 \%, 79 \%$ and $66 \%$, and having a friend/relative living there $41 \%, 62 \%$, $61 \%$ and $58 \%$. The differential between the influence of a friend/relative's recommendation of a country or institution (whether or not they themselves studied or have even visited there) - and their physical presence in the study nation, state or city - was not explicitly addressed in the current piece and is 
worthy of further investigation to disentangle these (perhaps) disparate influences.

Influence of an educational agent's recommendation was relatively low (M = 2.30 for the US, 2.22 for MI and 2.26 for MSU). Glover (2011) found similarly low levels of influence in the choice of Australia $(M=2.29$, rank 26/31) though the influence of an agent on the specific choice of the University of Queensland appeared slightly higher (2.78, 7/22). Yang (2007) noted the declining influence of agents among Chinese students. Items regarding the influence of educational agents were added at the recommendation of MSU's OISS, who noted the importance of agents, particularly in China; interestingly, however, there were no differences in the importance of agents between Chinese students and those of other origins with respect to choice of the USA or MI, and in the case of MSU, the influence of agents was rated less important by Chinese than other nationalities. Despite the low mean scores on the agent items, and relatively higher ranking of most other factors investigated, the proportions of students indicating that agent recommendations were very or extremely important in their decisions $(25.9 \%$ for the USA, $20.1 \%$ for MI, $22.4 \%)$ affirm the observation that the use of agents is neverthless more prevalent than most universities in the US tend to believe (Jaschik, 2014).

Unlike Pimpa (2003), who found qualitatively higher levels of agent influence over the choice of university than that of country or city, the MSU sample did not demonstrate any variation in agent impact across country, state or institution. It did, however, highlight the relatively higher levels of agent influence over undergraduate than graduate students in their choice of country, state and institution. This finding is intuitive given the more focused and specialized nature of graduate study, and that students seeking a graduate program are likely to be more informed about and invested in making the best decision to suit their individual academic needs, i.e., they are less likely to need to seek an outside opinion and more likely to conduct their own research.

Weather/climate was also found to be of little importance $(\mathrm{M}=$ 2.27). This contrasts with other studies that have found this to be a more influential factor, e.g., climate/weather was ranked the second most influential factor in the Western Australia study cited by Mazzarol and Hosie (1996) and weather ranked 4 of 31 items $(M=3.51 / 5.0)$ for Australia and 2 of 22 items (3.31) for Brisbane according to Glover (2011). This perhaps reflects the desirable nature of much of Australia's climatic 
conditions, in comparison to the temperate conditions and often harsh winters experienced in Michigan. It seems more likely that students choose Michigan despite its climate, or perhaps without much or any knowledge of it, rather than because of it. This proposition is supported by the observation that weather/climate failed to motivate students' choices in any of the northern European (UK, Ireland, Sweden) studies reviewed, a region sharing somewhat similar weather/climate conditions to those in MI, though this suggestion does require additional analysis prior to any more definitive statement can be made. It seems reasonable that for full time students committing to study abroad for two-four or more years, an attractive climate is an added bonus rather than one of the most critical deciding factors.

Opportunities to travel while in the USA were rated as only somewhat important $(M=3.14)$. The only other study that has considered this factor indicated the placing of greater priority on travel in the chosen nation; the items 'I want to travel in Australia,' 'Australia has interesting places to visit' and 'I want to explore the Australian landscape' ranked seventh, eight and tenth out of 31 items according to Glover (2011). However, the mean scores (3.42, 3.42 and 3.24 on a five-point strongly (dis)agree scale) were comparable to the present case. As noted by Glover, it is likely that full-time students place greater importance on educational aspects of their experience than those studying abroad for a shorter period. Nevertheless, given their numbers, and their propensity to receive guests from home during their stays, the potential size of the international student leisure travel market is not to be underestimated, presenting substantial destination marketing opportunities for states/provinces and cities within the nations chosen as study locations.

Proximity of the US to home ranked eighth of eight factors $(\mathrm{M}=$ 2.05). This contrasts with studies such as that cited by Mazzarol and Hosie (1996) as well as Shanka et al. (2006) in which closeness to home was an important factor; in both of those cases, however, the study location was Australia and most of the students surveyed were Asian, i.e., they lived relatively close by. It also contradicts migration-based studies that have shown distance to have a significant negative effect (Beine et al., 2014; Perkins \& Neumayer, 2014). It seems intuitive that students for whom proximity was a critical factor would have chosen a closer study destination, i.e., that for those European, African and Asian students at MSU, distance to home was a less important determinant. This suggestion is supported by Kemp, Madden and Simpson (1998), whose discrete destination choice 
model showed that for prospective students from Indonesia and Taiwan, Australia's chances of selection as a destination (relative to both the US, and the rest of the world) increased due to its geographic proximity. It is also possible that physical proximity has declined in relative importance with the advent of communications technologies that allow virtually constant, audio and visual contact whatever one's location. A recent study of prospective Chinese students found that distance from home ranked ninth of eleven sets of factors influencing propensity to study abroad $(\mathrm{M}=3.04 / 5.0)(\mathrm{Cao}, \mathrm{Zhu}$ \& Meng, 2016).

Overall, the findings confirm the importance for US universities such as MSU to (continue to) highlight three critical factors in their recruiting efforts: the overall quality of a US education, and the more specific reputation/rankings of the university and its individual departments and programs (especially important to graduate students, though less important to Chinese students than those of other nationalities); levels of safety/security at their location; and, their (relative) affordability. Quality and cost/affordability were the two most consistently identified influential factors in the prior studies reviewed; the current study also showed the especially high levels of influence of those two factors on decisions made by incoming graduate students. Differentiation of the educational offering, based on the development and maintenance of a distinctive and high quality image, clearly remains vital to maintaining competitive advantage in the international education arena (per early observations made by, e.g., Mazzarol \& Hosie (1996) and Ivy (2001)). Countries, states and institutions can all - from the perspective of international students as young consumers - be considered brands; awareness, perceptions and images thereof are therefore absolutely critical. Though the notion of branding in higher education is not a new one per se (see, e.g., Stephenson, Heckert \& Yerger, 2016), consideration of media via which to extend and strengthen said brands in the international arena remains underdeveloped, e.g., the establishment and active management of social media channels such as Facebook and Twitter (in multiple languages) by universities and their international offices. Related, and also not considered in this study, the role of international alumni is likely substantial in promulgating university prestige and reputation.

Undergraduate students appeared more influenced by natural and cultural setting - the beauty of Michigan's natural scenery, its location on the Great Lakes, and its weather/climate; the reputation of East Lansing as a 
city in which to live; the presence of other international students; the reputation of MSU's sports teams; and, the beauty of campus. The differences between undergraduate and graduate students in the factors that influence their choices overall suggest that while graduate students focus primarily on academics, undergraduates take a broader perspective that considers academic elements and lifestyle amenities in more equal measure. This differential seems reasonable given the likelihood that for most undergraduates, college represents their first long term stay away from home and thus is more likely to be considered as much a social as a learning opportunity. Earlier studies, though not focused on international students, noted the higher importance of the social environment for undergraduate over graduate students (Kallio, 1995) and that for prospective undergraduate students, attractiveness of social life is at least as important as quality of education in determining choice of school (Capraro, Patrick \& Wilson, 2004). Similarly, Broekemier and Seshadri (2000) found that prospective undergraduate students identified social life, friends attending an institution, and athletic programs as more important than did their parents with respect to college choice.

The factors of special interest to undergraduate students are all ones that could be emphasized not only by MSU in its online and in-person recruiting efforts, but also by Travel Michigan, the state's tourism promotion entity, which is housed within the Michigan Economic Development Corporation (MEDC). In comparison to Australia, where the role of international students in trade and economic development has been clearly recognized, relationships between universities and economic development agencies in the US appear not to be common. The Australian Trade Commission (Austrade), for example, maintains a page devoted to the attraction of international students, and individual regions and cities also maintain sites devoted to this market, e.g., the South Australian Tourism Commission and Study Adelaide. A review of all official US state tourism sites revealed that none currently host such information, representing an opportunity for Travel Michigan to be the first state to establish such an emphasis and for Michigan's colleges and universities to exploit a new marketing venue. Such a page might also highlight travel opportunities within the state, not only for the students but also for their visiting friends and relatives. 


\section{LIMITATIONS AND FUTURE RESEARCH}

This study focused on just one of thousands of universities in a single country; additional analysis at other sizes and types of institution in the US and in other countries would clearly be of benefit. Though the results may not be generalizable to all international students throughout the country, especially to students at small, private or specialized schools, it is likely that they are relatively representative of the large public universities that attract the highest numbers of international students across the Midwest portion of the nation.

Comparison of findings with and across prior studies was hindered by the many different modes of data collection and question/answer formats employed, e.g., earlier studies often used dichotomous (such as yes/no, check one, check all that apply) approaches that only allowed frequencies to be reported. The wording and meaning of location factors also continues to vary, e.g., sometimes the term 'climate' is used to refer solely to weatherrelated factors, whereas in other studies its meaning appears to encompass other (tangible and intangible) aspects of the local environment. Similarly, the notion of safety/security can be interpreted to range from petty crime to major terrorist threats. Use of a common set of items with clear definitions and a shared response scale would facilitate comparison across universities and nations, with regular conduct of a multi-institution, multi-nation study representing the ideal scenario in order to provide a consistent supply of valid and reliable data. More qualitative approaches that capture greater depth and far more nuanced meaning would however remain equally valuable as precursors to and/or follow-up after such larger-scale assessments.

Survey questions in this study only focused on the choice of the US, Michigan and MSU. Future studies would benefit from identification and analysis of students' evoked choice sets. In this case, the evoked (or consideration) set would consist of those countries, states or cities, and institutions from which a student made his/her final choice. Identification of this set, and understanding of how students chose between the locations in it, would be of immense value to institutions; in the case of MSU, for example, were the students who eventually came here deliberating between a range of options across multiple nations, or was the final decision based on a much narrower set of only US or only Midwestern options? Knowledge of who and where the competition is, and which factors led to the final 
decision regarding study destination, would further assist educational institutions in their marketing efforts, particularly with respect to more targeted and effective branding and product differentiation.

\section{REFERENCES}

Abubakar, B., Shanka, T., \& Muuka, G.N. (2010). Tertiary education: an investigation of location selection criteria and preferences by international students - the case of two Australian universities. Journal of Marketing for Higher Education, 20(1), 49-68.

Anayah, B., \& Kuk, L. (2015). The growth of international student enrollment at community colleges and implications. Community College Journal of Research and Practice, 39(12), 1099-1110.

Anders, M. (2014, April 21). Luxury cars on campus: Chinese students at MSU flock to BMWs, Maseratis, other high-end autos. mLive. Retrieved from http://www.mlive.com/lansing-news/index.ssf/2014/04/michigan_state_ chinese_student.html

Austin, L., \& Shen, L. (2016). Factors influencing Chinese students' decisions to study in the United States. Journal of International Students, 6(3), 722732.

Beine, M., Noël, R., \& Ragot, L. (2014). Determinants of the international mobility of students. Economics of Education Review, 41, 40-54.

Binsardi, A., \& Ekwulugo, F. (2003). International marketing of British education: research on the students' perceptions and the UK market penetration. Marketing Intelligence \& Planning, 21(5), 318-327.

Bourke, A. (2000). A model of the determinants of international trade in higher education. The Service Industries Journal, 20(1), 110-138.

Broekemier, G.M., \& Seshadri, S. (2000). Differences in college choice criteria between deciding students and their parents. Journal of Marketing for Higher Education, 9(3), 1-13.

Cao, C., Zhu, C., \& Meng, Q. (2016). A survey of the influencing factors for international academic mobility of Chinese university students. Higher Education Quarterly, 70(2), 200-220.

Capraro, A. J., Patrick, M. L. \& Wilson, M. (2004). Attracting college candidates: The impact of perceived social life. Journal of Marketing for Higher Education, 14(1), 93-106.

Counsell, D. (2011). Chinese students abroad: Why they choose the UK and how they see their future. China: An International Journal, 9(1), 48-71.

Crabtree, S., \& Nsubuga, F. (2012, July 6). Women feel less safe than men in many developed countries. Gallup. Retrieved from http://www.gallup.com/ poll/155402/Women-Feel-Less-Safe-Men-Developed-Countries.aspx 
Crompton, J. (1979). Motivations of pleasure vacations. Annals of Tourism Research, 6(4), 408-424.

Cubillo, J.M., Sánchez, J., \& Cerviño, J. (2006). International students' decisionmaking process. The International Journal of Education Management, 20(2), 101-115.

Glover, P. (2011). International students: linking education and travel. Journal of Travel \& Tourism Marketing, 28(2), 180-195.

Goldbart, J., Marshall, J., \& Evans, I.R. (2005). International students of speech and language therapy in the UK: Choices about where to study and whether to return. Higher Education, 50, 89-109.

Huang, S. E., \& Brown, N.E. (1996). First-year international graduate students in hospitality programs: school choice, career expectations, and academic adjustment. Hospitality Research Journal, 20(1), 109-117.

Institute of International Education (2016a). Open Doors ${ }^{\circledR} 2016$ "Fast Facts." Institute of International Education.

Institute of International Education (2016b). Open Doors Fact Sheet: Michigan. Institute of International Education.

Ivy, J. (2001). Higher education institution image: A correspondence analysis approach. The International Journal of Educational Management, 15(6), 276-282.

Jaschik, S. (2014). The agent impact. Inside Higher Ed. Retrieved from https://www.insidehighered.com/news/2014/05/01/new-data-use-agentsrecruit-international-students

Kallio, R.E. (1995). Factors influencing the college choice decisions of graduate students. Research in Higher Education, 36(1), 109-124.

Kemp, S., Madden, G., \& Simpson, M. (1998). Emerging Australian education markets: A discrete choice model of Taiwanese and Indonesian Student.

Maringe, F., \& Carter, S. (2007) International students' motivations for studying in the UK HI: insights into the choice and decision making of African students. International Journal of Educational Management, 21(6), 459475.

Mazzarol, T., \& Hosie, P. (1996). Exporting Australian higher education: future strategies in a maturing market. Quality Assurance in Education, 4(1), 37 50 .

Mazzarol, T., \& Soutar, G. N. (2001). "Push-pull” factors in international student destination choice. Discussion Paper No. 0105. Center for Entrepreneurial Management and Innovation. Retrieved from http://www.cemi.com.au/ sites/all/publications/CEMI\%20DP0105\%20Mazzarol\%20and\%20Soutar $\% 202001 . p d f$

Michael, I., Armstrong, A., \& King, B. (2004). The travel behavior of international students: The relationship between studying abroad and their choice of tourist destinations. Journal of Vacation Marketing, 10(1), 57-66. 
Miller, M. (2014, May 3). East Lansing's burgeoning Chinese population driving growing number of specialty businesses. Lansing State Journal. Retrieved from http://archive.lansingstatejournal.com/article/20140504/NEWS01/ 305040065/East-Lansing-s-burgeoning-Chinese-population-drivinggrowing-number-specialty-businesses

Mullins, G., Quintrell, N., \& Lisa Hancock (1995). The experiences of international and local students at three Australian Universities. Higher Education Research \& Development, 14(2), 201-231.

Office for International Students and Scholars (2015). 2015 Annual Report. East Lansing, MI: Michigan State University Office for International Students and Scholars.

Pandit, K. (2007). The importance of international students on our campuses. Yearbook of the Association of Pacific Coast Geographers, 69, 156-159.

Perkins, R., \& Neumayer, R. (2014). Geographies of educational mobilities: exploring the uneven flows of international students. The Geographical Journal, 180(3), 246-259.

Phang, S.L. (2013). Factors influencing international students' study destination decision abroad (Masters thesis). University of Gothenburg, Gothenburg, Sweden.

Pimpa, N. (2003). The influence of peers and student recruitment agencies on Thai students' choices of international education. Journal of Studies in International Education, 7(2), 178-192.

Pimpa, N. (2005). A family affair: the effect of family on Thai students' choices of international education. Higher Education, 49, 431-448.

Ratti, C. (2010). Campus safety at the University of Mary Washington. (Honor's Thesis). University of Mary Washington, Fredericksburg, VA. Retrived from http:/cas.umw.edu/geography/files/2011/09/Ratti_Thesis.pdf

Ruhanen, L., \& McLennan, C. J. (2010). 'Location, location, location'- the relative importance of country, institution and program: A study of tourism postgraduate students. Journal of Hospitality and Tourism Management, $17,44-52$.

Shanka, T., Quintal, V., \& Taylor, R. (2006) Factors influencing international students' choice of an education destination - a correspondence analysis. Journal of Marketing for Higher Education, 15(2), 31-46.

Smith, W.R., \& Torstensson, M. (1997). Gender differences in risk perception and neutralizing fear of crime: Toward Resolving the Paradoxes. British Journal of Criminology, 37(4), 608-634.

Srikatanyoo, N., \& Gnoth, J. (2002). Nation branding country image and international tertiary education. Brand Management, 10(2), 139-146.

Stephenson, A., Heckert, A., \& Yerger, D. (2016). College choice and the university brand: exploring the consumer decision framework. Higher Education, 71(4), 489-503. 
Tourism Australia (2016). Understanding Tourism Australia's International Consumer 2016. Retrieved from http://www.tourism.australia.com/ documents/Statistics/TASI10578_Aggregate_CDP_Fact_Sheet_Web.pdf

Yang, M. (2007). What attracts mainland Chinese students to Australian higher education. Studies in Learning, Evaluation Innovation and Development, $4(2), 1-12$.

Zhang, H.Q., Qu, H., \& Tang, V.M.Y. (2004). A case study of Hong Kong residents' outbound leisure travel. Tourism Management, 25(2), 267-273.

SARAH NICHOLLS, $\mathrm{PhD}$, is Associate Professor of Community Sustainability and Geography, Environment, \& Spatial Sciences. Her research focuses on the planning, development, management and impacts of tourism. Email: nicho210@msu.edu

Manuscript submitted: August 30, 2016 Manuscript revised: January 6, 2017 Accepted for publication: January 18, 2017 